\title{
Religious Upbringing and Neuroticism in Dutch Twin Families
}

\author{
Gonneke Willemsen and Dorret I. Boomsma \\ Department of Biological Psychology, VU University Amsterdam, Amsterdam, the Netherlands
}

Evidis vidence for a relation between neuroticism and religion is scarce and inconsistent. The aims of the present study were to determine the association of religious upbringing with adult neuroticism scores and to examine the effect of religious upbringing on the heritability of neuroticism. As part of a longitudinal survey of twin families from the Netherlands Twin Register, data were collected on neuroticism and religious upbringing. Restricting the sample to persons aged 25 and over resulted in a sample of 4369 twins and 1304 siblings from 2698 families. Religious upbringing was significantly associated with neuroticism; in both men and women neuroticism levels were lower in those who had received a religious upbringing. There were no sex or twinsibling differences in neuroticism variances and covariances. Structural equation modeling showed differences in heritability between those with and without religious upbringing. In the group with religious upbringing, variation in neuroticism was determined for $41 \%$ by additive genetic factors and for the remaining $59 \%$ by unique environmental factors. In the group who had not received a religious upbringing, variation in neuroticism was determined for $55 \%$ by genetic factors, with evidence for both additive and nonadditive factors, and for the remaining $45 \%$ by unique environmental influences. In conclusion, having received a religious upbringing is associated with lower neuroticism scores and a lower heritability in adulthood.

Neuroticism or emotional instability has frequently been linked to decreased mental and physical health (e.g., Almada et al., 1991; De Beurs et al., 2000, 2005; De Moor et al., 2006; Kendler et al., 2006; Khan et al., 2005; Hettema et al., 2006; Ormel et al., 2004; Spijkerman et al., 2005). Variation in neuroticism has been shown, through twin and family based studies, to be partly determined by genes, with broad heritability estimates generally ranging from $35 \%$ to $55 \%$ in adolescents and adults (e.g., Eaves et al., 1989; Lake et al., 2000; Keller et al., 2005; Rettew et al., 2006; Viken et al., 1994). Nongenetic factors will therefore also influence neuroticism, or interact with genetic factors in determining neuroticism levels. One factor which has been postulated to influence neuroticism but has received little support so far is religion (for a review see Saroglou, 2002). Religiousness as a psychological trait has been neglected by modern psychologists relative to most other psychological constructs (Bouchard et al., 1999), though recently more studies have appeared. Still, a problem in studying the effects of religion is the fact that there are many different aspects of religion and each may influence neuroticism, or for that matter other personality traits, differently. As reviewed by Saraglou (2002), neuroticism did not correlate significantly with religiosity, correlated negatively with open, mature religiosity and spirituality and with religious fundamentalism and positively with extrinsic religion. As relatively few studies exist, it is important to assess different aspects of religion in relation to neuroticism and other personality traits to determine the true mechanisms by which religion may affect personality.

The studies that examined religion in relation to neuroticism have mainly focused on adult aspects of religion. However, it is possible that the modifying effects of religion on neuroticism already occur during childhood through parenting effects. Although a large body of literature exists on parenting styles and later personality disorders (e.g., Frick et al., 1992; Johnson et al., 2006; Martin et al., 2004; Reti et al., 2002a; Smith \& Farrington, 2004; Willinger et al., 2002), generally providing evidence for an association, few studies so far examined the role of parenting on normal personality traits. In a study by Reti et al. (2002b) parenting style was related to neuroticism; neuroticism scores were higher in individuals who reported lower parental care and more parental intrusiveness. The present study will assess a particular aspect of parenting, namely religious upbringing, and address the question whether religious upbringing is associated with adult neuroticism levels.

If there is an association between religion and neuroticism, it is of interest to explore the mechanisms by which religion would influence neuroticism scores. One mechanism by which religion could influence

Received 31 January, 2007; accepted 1 February, 2007.

Address for correspondence: Gonneke Willemsen, Department of Biological Psychology, Vrije Universiteit Amsterdam, van der Boechorstraat 1, 1081 BT Amsterdam, the Netherlands. E-mail: ahm.willemsen@psy.vu.nl 
neuroticism is by changing the expression of genes for neuroticism, resulting in differences in the heritability of neuroticism for the different religion groups. This phenomenon is known as gene*environment (GE) interaction (Boomsma \& Martin, 2002; Kendler \& Eaves, 1986; Martin, 2000). Only one study has examined the effect of religion on the heritability of personality measures (see Kendler, 2001). Boomsma et al. (1999) looked at the effect of religious upbringing on disinhibition and found significant heritability for disinhibition only in the adolescent and young adult twins without a religious upbringing. Other studies on the effect of religious upbringing on heritability have focused on substance use. Heritability for alcohol use was found to be lower in adolescents and adults who received a religious upbringing than in those who did not receive a religious upbringing (Koopmans et al., 1999).

To assess the association between religious upbringing and neuroticism we used twin family data collected in longitudinal surveys of health, personality and lifestyle conducted by the Netherlands Twin Register. As we wanted to ensure most participants had left the family environment, we limited our study to individuals aged 25 years and older. In addition to twin data, we also included data for the additional siblings of the twins in our analyses, to determine whether the twin data may be generalised to singletons. The aims of the present study were twofold: (1) to determine the association of religious upbringing on adult neuroticism scores, and (2) to examine the effect of religious upbringing on the heritability of neuroticism.

\section{Methods \\ Participants}

In 1991 the Netherlands Twin Register started a longitudinal survey study of health, lifestyle and personality. Twins were recruited through addresses of adolescent and adult twins obtained from council registers, and through voluntary registration. Every two to three years a questionnaire booklet is sent to twins and their family members (Boomsma et al., 2002, 2006; Vink et al., 2004). For this paper, we selected twins and their siblings who completed a survey in 1991, 1993, 1997, 2000 or 2002 as at these time points data on neuroticism and religion were collected. Data on neuroticism were available for 8929 twins and 2463 siblings. For the analyses we only included data for individuals aged 25 years or over. For most participants, data were available at multiple time points. We selected the data obtained at the oldest age, but gave preference to the time points that twins participated at the same time. In addition to the twin data, we selected data for no more than two male and two female singleton siblings in addition to the twins, thereby excluding 14 male and six female siblings. For the siblings, we gave preference to the time points where the age difference with the twin was smallest. In the final sample for the analyses, valid data on religious upbringing and neuroticism were available for 4369 (1449 male, 2920 female) twins and 1304 (562 male, 742 female) siblings from 2698 families. Complete twin pair data were available for 231 monozygotic male (MZM), 144 dizygotic male (DZM), 642 monozygotic female (MZF), 330 dizygotic female (DZF) and 324 dizygotic opposite-sex (DOS) twin pairs. Data on male singleton siblings were present in 487 families, with data on two male siblings present in 75 families. In 602 families data on female singleton siblings were available, and in 140 of those families data were available for two female siblings.

\section{Zygosity}

Twin zygosity was determined from DNA polymorphisms (in $35.6 \%$ of same-sex twin pairs), or when DNA was not available, from survey questions. Every survey asked each of the twins whether they were alike in eye color, hair color, face color and face form. Twins also indicated whether they were as a child mistaken for each other by their parents, other family members, and strangers. Parents and siblings were also asked to answer these questions about the twins. Based on the answers to these questions, twin zygosity was determined for every occasion and person separately. Next, all individual judgments were combined to determine one measure of twin zygosity. Agreement between DNA zygosity and questionnaire zygosity is 97\% (Willemsen et al., 2005).

\section{Neuroticism}

Neuroticism was assessed with the Amsterdamse Biografische Vragenlijst (ABV), which includes neuroticism, extraversion, somatic complaints and test attitude scales. The item content of the ABV neuroticism scale is very similar to that of the Eysenck Personality Questionnaire (Wilde, 1970). The ABV was included in the surveys of 1991, 1993, 1997, 2000 and 2002. The neuroticism scale consisted of 30 items ( $\alpha=0.89$, averaged over surveys) with three answer categories.

\section{Religion}

Religious upbringing. In the surveys of 1993, 1995, 1997, 2000 and 2002 twins and siblings were asked whether they received a religious upbringing, with answer categories 'Yes' and 'No'. Discrepancies across time, twin pairs and their siblings were checked, and in case of inconsistencies the majority of the answers determined the status of the family. In case there were as many answers stating 'Yes' as 'No' religious upbringing was treated as missing for that family (3.9\% of the total sample).

\section{Analyses}

Using structural equation modeling, we first fitted a saturated model to the neuroticism data to determine within the groups with and without religious upbringing whether mean neuroticism scores could be equated for men and women, and twins and siblings. Next, we determined whether there was an age effect on neuroticism scores, and finally we looked at 
whether variances and correlations could be equated for men and women, and for DZ twins and siblings. Based on the estimated correlations for the $\mathrm{MZ}$ and DZ twins/siblings we determined whether we would fit either an ACE model, including additive genetic (A), common environmental (C), and unique environmental (E) effects, or an ADE model, in which genetic dominance effects (D) are modeled instead of C, to the data. In a twin design including $\mathrm{MZ}$ twins, DZ twins, and siblings, we are unable to simultaneously test for D and C, as these two estimates are confounded. As the correlations for neuroticism suggested the presence of $\mathrm{D}$, an ADE model was tested against the saturated model.

Correlations between the latent A factors were 1 for $\mathrm{MZ}$ twin pairs and .5 for $\mathrm{DZ}$ twin and sibling pairs, while correlations between the latent $D$ factors were 1 for $\mathrm{MZ}$ and .25 for $\mathrm{DZ}$ twin and sibling pairs. If mean differences between subjects with and without religious upbringing are associated with different error variances in the two groups, this would lead to different estimates for the proportion of unique environmental variance, and thus also to differences in heritability estimates, in the absence of any GE interaction. We therefore first tested for heteroscedasticity by comparing the full model to a model in which the estimates for unique environmental influences were constrained to be equal in the two religious groups (Boomsma et al., 1999). Next, genetic models were fit and the estimates for the genetic variances compared across groups. The test of GE interaction involved testing whether the variance explained by genes and environment could be equated in the groups with and without a religious upbringing. All structural equation modeling was carried out in Mx (Neale et al., 2003). Likelihood ratio tests were used to assess sex and twin-sibling differences in variances and covariances and to test the significance of variance components $\mathrm{A}$ and $\mathrm{D}$ and the constraints that variance components were equal across groups.

\section{Results}

Table 1 shows the sample characteristics and the mean neuroticism scores in the twin and sibling population separately for men and women. For both groups it was found that men scored lower on neuroticism than women, there were no differences in mean scores for twins and siblings, and there was no significant age effect on neuroticism scores. Table 2 provides the estimated correlations for twins and siblings with and without religious upbringing. Further model fitting showed that sex or being a DZ twin or singleton sibling did not affect variance and covariance in neuroticism. We therefore continued with a model in which a sex effect on mean neuroticism scores was included, male and female estimates for variance and covariances were equated, and mean neuroticism scores, variances and covariance for DZ twins and singleton siblings were equated. In the group with

\section{Table 1}

Average (SD) Age and Neuroticism Scores for Men and Women With and Without Religious Upbringing

\begin{tabular}{lcccc}
\hline & \multicolumn{2}{c}{ Religious upbringing } & \multicolumn{2}{c}{ No religious upbringing } \\
\hline & Men & Women & Men & Women \\
\hline$N$ & 1304 & 2491 & 707 & 1171 \\
Age & $36.82(12.07)$ & $36.99(11.39)$ & $32.04(9.44)$ & $31.23(7.50)$ \\
Neuroticism & $39.54(22.15)$ & $46.59(24.99)$ & $42.88(24.6)$ & $52.35(25.61)$ \\
\hline
\end{tabular}

religious upbringing the estimated correlation for neuroticism was .44 (confidence interval $[\mathrm{CI}]=.37-.50$ ) for the $\mathrm{MZ}$ twins and $.17(\mathrm{CI}=.12-.22)$ for the $\mathrm{DZ}$ twins/siblings. In the group without religious upbringing the estimated correlation for neuroticism was .55 ( $\mathrm{CI}=.48-.62)$ for the $\mathrm{MZ}$ twins and $.15(\mathrm{CI}=.07-.22)$ for the $\mathrm{DZ}$ twins/siblings. The difference between the $\mathrm{MZ}$ and DZ twins, particularly in the group without religious upbringing, seems to indicate there may be a genetic dominance effect. We therefore tested an ADEmodel. As MZ correlations are higher and DZ correlations are lower in the group without religious upbringing compared to the group with religious upbringing this suggests there may be a higher heritability in the group without religious upbringing.

Table 3 shows the fit statistics for the genetic models in the simultaneous analysis of the data from the groups with and without religious upbringing. First, we determined there was no heteroscedasticity as unique environmental variances could be equated in both groups. Following this, the effect of religious upbringing on mean neuroticism was examined; those with a religious upbringing had significantly lower neuroticism scores than those without religious upbringing. When next examining whether $\mathrm{D}$ could be dropped for each of the groups, a group difference emerged. In the group with religious upbringing the influence of $\mathrm{D}$ was not significant, while in the group without religious upbringing $\mathrm{D}$ could not be removed

\section{Table 2}

ML Estimates of Correlations (95\% Cl) for Twin and Sibling Pairs by Religious Upbringing

\begin{tabular}{lcc}
\hline & Religious upbringing & No religious upbringing \\
\hline MZM twins & $.398(.251-.525)$ & $.554(.397-.674)$ \\
DZM twins & $.261(.069-.426)$ & $.258(-.055-.499)$ \\
MZF twins & $.446(.369-.517)$ & $.569(.475-.649)$ \\
DZF twins & $.224(.089-.347)$ & $.140(-.048-.315)$ \\
DOS twins & $.143(.022-.257)$ & $.188(-.004-.359)$ \\
Male siblings & $.058(-.018-.283)$ & $.055(-.524-.569)$ \\
Female siblings & $.217(.046-.370)$ & $.190(-.237-.527)$ \\
Opposite sex siblings & $.129(-.009-.258)$ & $.046(-.375-.431)$ \\
\hline Note: Sibling pairs may consist of two singleton siblings or a twin and its singleton \\
\multicolumn{1}{c}{ sibling. }
\end{tabular}


Table 3

Model-Fitting Results for the Genetic Models in the Groups With and Without Religious Upbringing

\begin{tabular}{|c|c|c|c|c|c|}
\hline Model & Compared to model & $-2 \mathrm{LL}$ & $d f$ & $\Delta \chi$ & $p$ \\
\hline 1. Full model & & $22,203.394$ & 5664 & & \\
\hline 2. Heteroscedasticity: Equate E variance in both groups & 1 & $22,206.815$ & 5665 & 3.422 & .064 \\
\hline 3. Equate means in both groups & 1 & $22,220.850$ & 5666 & 17.456 & .000 \\
\hline 4. Drop $D$ variance for religious upbringing & 1 & $22,206.580$ & 5665 & 3.187 & .074 \\
\hline 5. Drop D variance for no religious upbringing & 4 & $22,216.641$ & 5666 & 10.061 & .002 \\
\hline 6. Equate $A$ variance for both groups & 4 & $22,211.420$ & 5666 & 5.241 & .022 \\
\hline
\end{tabular}

from the model without a significant worsening of fit. Further, the amount of variance explained by additive genetic factors could not be equated in the two groups.

In the best fitting model, individual differences in neuroticism for the group with religious upbringing were explained for $41 \%$ (CI 35-46) by additive genetic factors and for the remainder by unique environmental influences, while in the group without religious upbringing, individual differences were due to both additive and nonadditive genetic factors $(\mathrm{D}=52 \%[\mathrm{CI}=20-62]$ and $\mathrm{A}=3 \%[\mathrm{CI}=0-34])$, resulting in a broad heritability estimate of $55 \%$.

To determine whether the differences in variance components between the two groups may have been due to differences in the age distribution of the two groups, as the group without religious upbringing included a smaller number of older aged participants, we reran the analyses while restricting both groups to a narrow age band of 25 to 35 years. Similar results were found (model-fitting results not shown). Again, broad heritability was higher in the group without religious upbringing $(53 \%)$ with both additive $(32 \%)$ and nonadditive genetic effects $(21 \%)$ present, while in the group with religious upbringing the variation in neuroticism was explained for $35 \%$ by additive genetic effects and for the remainder by unique environmental factors. The only difference with the previous analyses in the total group was that in this narrow age band the variance explained by additive genetic factors could be equated in both groups.

In summary, religious upbringing is associated with lower neuroticism. At least part of this association is due to the modifying effect of religious upbringing on the genetic determinants of neuroticism.

\section{Discussion}

The first aim of the present study was to establish whether religion, experienced in childhood through religious upbringing influenced adult neuroticism levels. In this sample of Dutch twins and siblings, neuroticism scores were lower in individuals who had received a religious upbringing compared to individuals who had not received a religious upbringing, though admittedly differences were small. These effects were seen in both men and women, with women, as expected, having consistently higher neu- roticism scores than men. Though most studies have reported an absence of an association between religiosity and neuroticism (e.g., Fearn et al., 2003; Saraglou, 2002), negative associations have been reported previously (Kendler et al., 1999; Saraglou, 2002). Our results further add to the conclusion in Saroglou's (2002) review that the association between religion and personality, in this case neuroticism, may depend on the aspect of religion measured. The aspect of religion used in this study, religious upbringing, is likely to reflect the family-based, social components of religion, while the more often studied religiosity generally represents an internal construct. In that view it may not be surprising that our more social aspect of religion is associated with a lower neuroticism level.

Although gradually religion is becoming less important in the Netherlands, the fact that religion has been a cornerstone of Dutch society is still evident in our sample, as the majority of persons had received a religious upbringing. In fact, the small number of individuals without religious upbringing in older age groups did not allow us to rerun our analyses in older age groups. This seems to suggest that at present, in the older generations, most individuals will experience the beneficial effects of religious upbringing on neuroticism. The true estimate of the effect of religious upbringing on neuroticism will most likely become more apparent in the next generations, when the number of families without religious upbringing increases. If religion indeed leads to lower neuroticism scores, we may expect increases in neuroticism scores in the current generations compared to the older generations.

For religious upbringing, the variation is almost by definition explained by between-family differences (or common environment shared by family members). We therefore computed a family based measure for religious upbringing from the self-report data by the participants. Although consistency across time and across family members is very high $(>85 \%)$ we cannot fully exclude the possibility that an individual's perception of religious upbringing is influenced by his or her neuroticism level. To shed more light on this, we assessed the data on religious beliefs provided by the parents of the twins and siblings in our sample. We had parental data for 475 families in which, 
according to the offspring, no religious upbringing occurred. In these families, $47 \%$ of the parents reported not to be religious, in $12 \%$ only one of the parents was religious, and in $36 \%$ both parents reported a religious affiliation (predominantly Roman Catholic or Protestant). For those families in which the offspring reported religious upbringing, we had parental data in 761 cases. In these families $94 \%$ of the parents reported a religious affiliation (again predominantly Roman Catholic or Protestant), and in less than $1 \%$ of the families both parents reported to be not religious. Overall, these data seemed to indicate that offspring perception of religious upbringing corresponds well with parental data, making it unlikely that neuroticism influenced their self-report of religious upbringing.

A second aim of the present study was to determine whether religion modified the heritability of neuroticism. Indeed, the genetic effects on neuroticism were different for the two groups. Not only was the heritability higher in those without religious upbringing, but our results also suggested differences in the genetic architecture in the two groups, with nonadditive effects present in the group without religious upbringing, but not in the group with religious upbringing. As the groups differed in age, with a larger amount of older individuals in the group with religious upbringing, the differences in genetic influences may also have reflected an age effect. However, restricting the analyses to a narrow age range provided similar results, suggesting that the difference in age distribution does not explain the difference between the two groups. Though broad heritability estimates differed between the groups, the estimates were within the range of heritability estimates found in previous studies (e.g., Eaves et al., 1989; Lake et al., 2000; Keller et al., 2005, Rettew et al., 2006; Viken et al., 1994). In the group without religious upbringing, the presence of nonadditive genetic effects was indicated. Nonadditive genetic effects have been previously reported in other studies (Eaves et al., 1998; 1999; Keller et al., 2005; Lake et al., 2000), using an extended twin-design. It is difficult to distinguish between the estimates of additive and nonadditive genetic effects, since these are correlated in the twin design (as opposed to the true population effects, which by definition are uncorrelated: Falconer \& Mackay, 1996; Keller et al., 2005; Posthuma et al., 2001). This is reflected in the large and overlapping confidence intervals around these estimates in our study. Although a more precise estimate of the quantitative contribution of nonadditive genetic effects can only be obtained when adding multiple genetic relationships, our results do suggest the presence of nonadditive genetic effects in the group without a religious upbringing. An interesting hypothesis is that the sometimes conflicting results reported in the literature for the contribution of genetic dominance could reflect the differences in religious upbringing between samples.

\section{Acknowledgments}

We would like to acknowledge the following grants: Genetic basis of anxiety and depression (NWO 90461-090); Database Twin register (NWO 575-25-006); Genetics of individual differences in smoking (NWO 985-10-002); Resolving cause and effect in the association between regular exercise and psychological well-being (NWO-MW 904-61-193); Spinozapremie (NWO/SPI 56-464-14192); CNCR-VU (Centre Neurogenomics and Cognition Research); Center Medical Systems Biology (NWO Genomics); Twinfamily database for behavior genetics and genomics (NWO 480-04-004).

The authors acknowledge funding support from the National Institute on Aging. The views expressed are those of the authors of this paper, and not the National Institute on Aging, the National Institutes of Health or the Department of Health and Human Services.

\section{References}

Almada, S. J., Zonderman, A. B., Shekelle, R. B., Dyer, A. R., Daviglus, M. L., Costa, P. T., Jr., \& Stamler, J. (1991). Neuroticism and cynicism and risk of death in middle-aged men: The Western Electric Study. Psychosomatic Medicine, 53, 165-175.

Boomsma, D. I., de Geus, E. J. C., van Baal, G. C. M., \& Koopmans, J. R. (1999). Religious upbringing reduces the influence of genetic factors on disinhibition: Evidence for interaction between genotype and environment. Twin Research, 2, 115-125.

Boomsma, D. I., de Geus, E. J. C., Vink, J. M., Stubbe, J. H., Distel, M. A., Hottenga, J. J., Posthuma, D., van Beijsterveldt, C. E. M., Hudziak, J. J., Bartels, M., \& Willemsen, G. (2006). Netherlands Twin Register: from twins to twin families. Twin Research and Human Genetics, 9, 849-857.

Boomsma, D. I., \& Martin, N. G. (2002). Gene-environment interactions. In H. D'haenen, J. A., den Boer, \& P. Wilner (Eds.), Biological psychiatry (pp. 181-187). Hoboken, NJ: John Wiley \& Sons Ltd.

Boomsma, D. I., Vink, J. M., van Beijsterveldt, T. C., de Geus, E. J., Beem, A. L., Mulder, E. J., Derks, E. M., Riese, H., Willemsen, G. A., Bartels, M., van den Berg, M., Kupper, N. H., Polderman, T. J., Posthuma, D., Rietveld, M. J., Stubbe, J. H., Knol, L. I., Stroet, T., \& van Baal, G. C. (2002). Netherlands Twin Register: A focus on longitudinal research. Twin Research, 5, 401-406.

Bouchard, T. J., Jr., McGue, M., Lykken, D., \& Tellegen, A. (1999). Intrinsic and extrinsic religiousness: Genetic and environmental influences and personality correlates. Twin Research, 2, 88-98.

de Beurs, E., Beekman, A. T., Deeg, D. J., Van Dyck, R., van Tilburg, W. (2000). Predictors of change in anxiety symptoms of older persons: Results from the Longitudinal Aging Study Amsterdam. Psychological Medicine, 30, 515-527. 
de Beurs, E., Comijs, H., Twisk, J. W., Sonnenberg, C., Beekman, A. T., Deeg, D. (2005). Stability and change of emotional functioning in late life: Modelling of vulnerability profiles. Journal of Affective Disorders, $84,53-62$.

de Moor, M. H., Beem, A. L., Stubbe, J. H., Boomsma, D. I., De Geus, E. J. (2006). Regular exercise, anxiety, depression and personality: A population-based study. Preventive Medicine, 42, 273-279.

Eaves, L. J., Eysenck, H. J., \& Martin, N. G. (1989). Genes, culture and personality: An empirical approach. London: Academic Press.

Eaves, L. J., Heath, A. C., Neale, M. C., Hewitt, J. K., \& Martin, N. G. (1998). Sex differences and non-additivity in the effects of genes on personality. Twin Research, 1, 131-137.

Eaves, L., Heath, A., Martin, N., Maes, H., Neale, M., Kendler, K., Kirk, K., \& Corey, L. (1999). Comparing the biological and cultural inheritance of personality and social attitudes in the Virginia 30,000 study of twins and their relatives. Twin Research, 2, 62-80.

Falconer, D. S., \& Mackay, T. F. C. (1996). Quantitative genetics. Essex: Longman Group Ltd.

Fearn, M., Lewis, C. A., \& Francis, L. J. (2003). Religion and personality among religious studies students: A replication. Psychological Reports, 93, 819-822.

Frick, P. J., Lahey, B. B., Loeber, R., Stouthamer-Loeber, M., Christ, M. A., \& Hanson, K. (1992). Familial risk factors to oppositional defiant disorder and conduct disorder: Parental psychopathology and maternal parenting. Journal of Consulting and Clinical Psychology, $60,49-55$.

Johnson, J. G., Cohen, P., Chen, H., Kasen, S., \& Brook, J. S. (2006). Parenting behaviors associated with risk for offspring personality disorder during adulthood. Archives of General Psychiatry, 63, 579-587.

Hettema, J. M., Neale, M. C., Myers, J. M., Prescott, C. A., \& Kendler, K. S. (2006). A population-based twin study of the relationship between neuroticism and internalizing disorders. American Journal of Psychiatry, 163, 857-864.

Kendler, K. S. (2001). Twin studies of psychiatric illness: An update. Archives of General Psychiatry, 58, 1005-1114.

Kendler, K. S., \& Eaves, L. J. (1986). Models for the joint effect of genotype and environment on liability to psychiatric illness. American Journal of Psychiatry 143, 279-289.

Kendler, K. S., Gardner, C. O., \& Prescott, C. A. (1999). Clarifying the relationship between religiosity and psychiatric illness: The impact of covariates and the specificity of buffering effects. Twin Research, 2, 137-144.

Kendler, K. S., Gatz, M., Gardner, C. O., \& Pedersen, N. L. (2006). Personality and major depression: A Swedish longitudinal, population-based twin study. Archives of General Psychiatry, 63, 1113-1120.
Keller, M. C., Coventry, W. L., Heath, A. C., \& Martin, N. G. (2005). Widespread evidence for non-additive genetic variation in Cloninger's and Eysenck's personality dimensions using a twin plus sibling design. Behavior Genetics, 35, 707-721.

Khan, A. A., Jacobson, K. C., Gardner, C. O., Prescott, C. A., \& Kendler, K. S. (2005). Personality and comorbidity of common psychiatric disorders. British Journal of Psychiatry, 186, 190-196.

Koopmans, J. R., Slutske, W. S., van Baal, G. C. M., \& Boomsma, D. I. (1999). The influence of religion on alcohol initiation: Evidence for genotype $\mathrm{X}$ environment interaction. Behavior Genetics, 29, 445-453.

Lake, R. I., Eaves, L. J., Mae, H. H., Heath, A. C., \& Martin, N. G. (2000). Further evidence against the environmental transmission of individual differences in neuroticism from a collaborative study of 45,850 twins and relatives on two continents. Behavior Genetics, 30, 223-233.

Martin, N. G. (2000) Gene-environment interaction and twin studies. In T. Spector, H. Snieder, \& A. MacGregor (Eds.), Advances in twin and sib-pair analysis (pp. 143-150). London: Greenwich Medical Media.

Martin, G., Bergen, H. A., Roeger, L., \& Allison, S. (2004). Depression in young adolescents: Investigations using 2 and 3 factor versions of the Parental Bonding Instrument. Journal of Nervous and Mental Disease, 192, 650-657.

Neale, M. C., Boker, S. M., Xie, G., \& Maes, H. H. (2003). Mx: Statistical modeling (6th ed.). Richmond, VA: Virginia Commonwealth University, Department of Psychiatry.

Ormel, J., Rosmalen, J., \& Farmer, A. (2004). Neuroticism: A non-informative marker of vulnerability to psychopathology. Social Psychiatry and Psychiatric Epidemiology, 39, 906-912.

Posthuma, D., Neale, M. C., Boomsma, D. I., \& de Geus, E. J. (2001). Are smarter brains running faster? Heritability of alpha peak frequency, IQ, and their interrelation. Behavior Genetics, 31, 567-579.

Reti, I. M., Samuels, J. F., Eaton, W. W., Bienvenu, O. J., 3rd, Costa, P. T., Jr, \& Nestadt, G. (2002a). Adult antisocial personality traits are associated with experiences of low parental care and maternal overprotection. Acta Psychiatrica Scandinavica, 106, 126-33.

Reti, I. M., Samuels, J. F., Eaton, W. W., Bienvenu, O. J., 3rd, Costa, P. T., Jr, \& Nestadt, G. (2002b). Influences of parenting on normal personality traits. Psychiatry Research, 111, 55-64.

Rettew, D. C., Vink, J. M., Willemsen, G., Doyle, A., Hudziak, J. J., \& Boomsma, D. I. (2006). The genetic architecture of neuroticism in 3301 Dutch adolescent twins as a function of age and sex: A study from the Dutch twin register. Twin Research and Human Genetics, 9, 24-29. 
Saroglou, V. (2002). Religion and the five factors of personality: A meta-analytic review. Personality and Individual Differences, 32, 15-25.

Smith, C. A., \& Farrington, D. P. (2004). Continuities in antisocial behavior and parenting across three generations. Journal of Child Psychology and Psychiatry, and Allied Disciplines, 45, 230-247.

Spijkerman, T., de Jonge, P., van den Brink, R. H., Jansen, J. H., May, J. F., Crijns, H. J., \& Ormel, J. (2005). Depression following myocardial infarction: First-ever versus ongoing and recurrent episodes. General Hospital Psychiatry, 27, 411-417.

Viken, R. J., Rose, R. J., Kaprio, J., \& Koskenvuo, M. (1994). A developmental genetic analysis of adult personality: Extraversion and neuroticism from 18 to 59 years of age. Journal of Personality and Social Psychology, 66, 722-730.

Vink, J. M., Willemsen, G., Stubbe, J. H., Middeldorp, C. M., Ligthart, R. S., Baas, K. D., Dirkzwager, H. J., de Geus, E. J., \& Boomsma, D. I. (2004). Estimating non-response bias in family studies: Application to mental health and lifestyle. European Journal of Epidemiology, 19, 623-630.

Wilde, G. J. S. (1970). Neurotische labiliteit gemeten volgens de vragenlijstmethode [The questionnaire method as a means of measuring neurotic instability]. Amsterdam: Van Rossen.

Willemsen, G., Posthuma, D., \& Boomsma, D. I. (2005). Environmental factors determine where the Dutch live: Results from the Netherlands Twin Register. Twin Research and Human Genetics, 8, 312-317.

Willinger, U., Heiden, A. M., Meszaros, K., Formann, A. K., \& Aschauer, H. N. (2002). Maternal bonding behaviour in schizophrenia and schizoaffective disorder, considering premorbid personality traits. Australian and New Zealand Journal of Psychiatry, 36, 663-668. 